\title{
Omega-3 Fatty Acids Insufficiency in Post Traumatic Brain Injury Patient (TBI) Attending Neurosurgery Clinics at Khola Hospital in Muscat- Sultanate of Oman
}

\author{
Ghazi Daradkeh $^{1,2,5}{ }^{*}$, Musthafa Mohamed Essa ${ }^{1,2}$, Ali AL- Maashani ${ }^{4}$, Samir Al-Adawi ${ }^{2,3}$, R. Koshi ${ }^{2}$, Sameera AL-Abrawi ${ }^{4}$, \\ Rayan Amiri ${ }^{4}$ and Jokha Al Barashdi ${ }^{4}$ \\ ${ }^{1}$ Department of Food Science and Nutrition, College of Agricultural and Marine Sciences, Sultan Qaboos University, Oman. \\ ${ }^{2}$ Ageing and Dementia Research Group, Sultan Qaboos University, Oman \\ ${ }^{3}$ Department of Behavioural Medicine, College of Medicine and Health Sciences, Sultan Qaboos University, Oman \\ ${ }^{4}$ Khoula Hospital, Ministry of Health, Oman \\ ${ }^{5}$ Hamad Medical Corporation, Qatar
}

\section{Abstract}

Background: Traumatic brain injury (TBI) is an acquired brain trauma that occurs when any sudden trauma/injury causes damage to the brain. TBI is characterized by tissue damage and imbalance in the cerebral blood flow and metabolism. It has been established through laboratory experiments that the dietary supplementation of omega- 3 fatty acids (FAs) could reduce the oxidative stress developed in the brain due to TBI. The inclusion of omega-3 FAs in diet could normalize the levels of brain-derived neurotrophic factor (BDNF), and thus, it could restore the survival of neuronal cells that improves the synaptic transmission.

Method: A total of 71 Posttraumatic brain injury Patients (PTBIP) aged 18-65 years, males and females participated in a cross-sectional study in Khola hospital (trauma center) Sultanate of Oman. The intake of omega -3 FAs were calculated from a dietary intake assessment using 24 hour-recall diet history.

Results: The Average intake of omega -3 in both males $(1.1 \mathrm{gm} / \mathrm{d})$ and females $(0.65 \mathrm{gm} / \mathrm{d})$ was significantly inadequate compared with the RDA $(1.6 \mathrm{gm} / \mathrm{d}$ and $1.1 \mathrm{gm} / \mathrm{d})$ among males and females respectively $\mathrm{P}<$ 0.05 . There was a positive association between the dietary intake of omega-3 FAs and BMI. The severity of Traumatic brain injury as measured by GCS has been inversely correlated with the intake of omega-3-FAs.

Conclusions: Inadequate dietary intake of omega-3 FAs is common in post-traumatic brain injury patients. Thus, omega-3 FAs supplements could be considered as a therapeutic option to reduce the secondary neuronal damages initiated by TBI.

\section{Introduction}

Traumatic brain injury (TBI) remains a significant cause of death and permanent disability worldwide. The Centers for Disease Control and Prevention (CDC) estimates that 1.7 million people in the United States sustain a TBI each year [1]. In the United States, sports-related TBIs estimated by 1.6-3.8 million annually, including those not treated by a health care provider $[2,3]$

TBI may be an acute and chronic process. Although the immediate consequences of brain injury can be devastating, long-term health disorders associated with TBI include posttraumatic stress disorder (PTSD), neurocognitive deficits, neurodegenerative diseases (Alzheimer's disease or Parkinsonism), psychosocial health problems (e.g. major depression, impairment of social functioning and ability to work and suicide), epilepsy, pain and other alterations in personality or behavior [4-6]. TBI is a multifaceted disease with prolonged secondary pathogenesis and long-lasting adverse neurological sequelae that remains a clinical challenge to manage.

Natural products and their active nutrients/components often cause possible improvement in most of the brain-related damages [7]. Omega-3 FAs are polyunsaturated fatty acids (PUFAs) having a double bond at the third position from the end of the FA chain. They are highly essential for maintaining the membrane fluidity and are present in all tissues, but are rich particularly in retina, brain, and spermatozoa. There are three important physiological omega-3 FAs available, including alpha-linolenic acid (ALA), eicosapentaenoic acid (EPA), and docosahexaenoic acid (DHA). Dietary omega-3 FAs are the precursors for the FA components of the neuronal membrane and are essential for maintaining the structural balance of cell membranes, signaling, neurotransmission, and modulation of enzymatic activity [8].

A growing body of preclinical data has shown that nutritional intervention, such as dietary supplementation with omega-3 (also known as n-3) FAs, may be of therapeutic benefit in acute injury to the brain [9-12]. Omega-3 FAs have long been known to play a restorative role in several pathways implicated in traumatic insult to the brain [11,13-16]. Emerging clinical evidence from both animal models and human studies of other brain injuries continue to suggest that they may provide benefits [16-18].

The most important n-3 FAs for human health and nutrition are docosahexaenoic acid (DHA), eicosapentaenoic acid (EPA), and

*Corresponding Author: Dr. Ghazi Daradkeh, Department of Dietetics and Clinical Nutrition, Al-Khor Hospital, Hamad Medical Corporation, Qatar, Tel: +974 5526 4714; E-mail: gdaradkeh@hamad.qa

Citation: Daradkeh G, Essa MM, AL-Maashani A, Al-Adawi S, Koshi R, et al. (2018) Omega-3 Fatty Acids Insufficiency in Post Traumatic Brain Injury Patient (TBI) Attending Neurosurgery Clinics at Khola Hospital in Muscat- Sultanate of Oman. Int J Clin Nutr Diet 4: 136 doi: https://doi.org/10.15344/2456-8171/2018/136

Copyright: (C) 2018 Daradkeh, et al. This is an open-access article distributed under the terms of the Creative Commons Attribution License, which permits unrestricted use, distribution, and reproduction in any medium, provided the original author and source are credited. 
Citation: Daradkeh G, Essa MM, AL-Maashani A, Al-Adawi S, Koshi R, et al. (2018) Omega-3 Fatty Acids Insufficiency in Post Traumatic Brain Injury Patient (TBI) Attending Neurosurgery Clinics at Khola Hospital in Muscat- Sultanate of Oman. Int J Clin Nutr Diet 4: 136 doi: https://doi.org/10.15344/2456-8171/2018/136

alpha-linolenic acid (ALA). Omega-3 FAs must be obtained from diet, and are highly enriched in algal oil, krill, and cold water fish [1921]. Poultry and eggs also provide small quantities of EPA and DHA, [22] while nuts, soybean, canola, and flax seed oils are major dietary sources of ALA [23]. Humans can also convert a limited amount of ALA into EPA and DHA, but a synthesis of EPA and especially DHA from ALA isinsufficient to supplant dietary intake [24].

The human brain consists of $60 \%$ lipid by dry weight, and docosahexaenoic acid is one of the most abundant fatty acids found in the solid matter of the brain [25]. DHA is aprimary structural component of the mammalian cerebral cortex and comprises $50 \%$ of neuronal membrane phospholipids [26]. Omega-3 FAs are essential for maintaining membrane fluidity [27], which in turn impacts neuronal cell adhesion, axon guidance, synapse maintenance, dendritic formation, and the speed of neurotransmission [28-30] DHA, for instance, is the longest and most unsaturated fatty acid found in biological membranes, with a structure that is tremendously flexible and therefore versatile [31]. It is capable of undergoing rapid interconversions between multiple torsional states and is unique in its ability to significantly alter membrane order and fluidity, phase behavior, elastic compressibility, ion permeability, and fusion [32-39].

Omega-3 FAs are so essential to and enriched in the brain due to their unique transformation into neuroprotective metabolites, which are critical in the defense against oxidative stress, tissue inflammation, and maintenance of synaptic integrity [40-42]. For example, during tissue stress, both EPA and DHA are thought to be released from membrane phospholipids and converted into compounds called "resolvins," which actively promote resolution of inflammatory processes, such as via down-regulation of NF- $\kappa \mathrm{B}$ and clearance of neutrophils [43-45].

Chronic dietary deprivation of n-3 FAs in animals leads to (1) decreased mean cell body size in neurons of the hippocampus, hypothalamus, and parietal cortex; (2) reduced the complexity of dendritic arborizations on cortical neurons; and (3) significant deficits in spatial learning and memory [46-50]. In contrast, increased brain levels of DHA in adult mice enhances hippocampal neurogenesis as evidenced by an increased number of proliferating neurons, increased neurite outgrowth, and increased density of dendritic spines, all of which correlate with markedly improved performance in spatial learning tasks [51]. In addition to serving as building blocks for membrane synthesis and modulating gene expression during neurogenesis, n-3 FAs are also involved in regulating neurotransmitter receptor levels and activity $[47,48]$. Performance of memory tasks was improved by increase intake of n-3 FAs in rats [52]. Impaired attention and poor performance were reported in rodents subjected to chronic omega-3 FAs deficiency [53-56]. Through mechanisms that are still incompletely understood, dietary supplementation with omega-3 FAs has been shown to significantly decrease the production of reactive oxygen species (ROS) and improve cognitive function in vivo [57 -58]. Polyunsaturated fatty acids in humans, particularly DHA, serve an essential role in nervous system development and are required for proper synaptogenesis, neural membrane synthesis, and the building of functionally critical circuits within the brain [59]. DHA deficiency is associated with aging and neurodegenerative conditions such as Alzheimer's disease [59], while DHA adequate consumption has been shown to improve performance on visuospatial learning and memory tasks in patients with age-related cognitive decline [60].
There is additional evidence in humans that dietary supplementation with omega-3 FAs improves functional recovery in subarachnoid hemorrhage and stroke [61-64]. DHA also has antioxidant activity and mitigates peroxidative damage of lipids and proteins in the brain [23], in addition to that DHA can attenuate neuronal death and cognitive and locomotor impairments in animal models of ischemiareperfusion injury to the brain [65-67], so it can be reasonably hypothesized that accumulation of omega- 3 FAs in the brain might also be neuroprotective in TBI. The aim of this study is to investigate the adequacy of omega -3 FAs intake in post-traumatic brain injury patients.

\section{Methodology}

The ethics committee of our institution approved this study andpatients' written informed consent was obtained (MERC/11/03). This study was conducted in an outpatient neurosurgery clinic at Khoula Hospital (National Trauma Center)-Muscat-Sultanate of Oman. 71 TBI adultpatients, aged 18-65 years, males and females participated in this study. Patients were invited to participate in an anonymous survey. This invitation was extended during routine outpatient visits. The exclusion criterion included: pre-injury psychiatric orneurological history other than those resulting from a TBI, non-Omanipatients and those who were known to have cognitive impairments that would preclude completion of the protracted assessment.

\section{Demographic and Anthropometric Measurements}

Demographic information, including age, sex, and education level, marital and smoking status were collected using a structured questionnaire. Weight was measured in kilogram to the nearest $0.1 \mathrm{~kg}$ using a digital weighing scale (Seca 208, Vogal and Halke, Germany). Height was measured to the nearest $0.5 \mathrm{~cm}$ by using a stadiometer protocol adapted from Lohman et al. [68] with a vertical measuring scale fixed to a metal bar connected to weighing scale.

Body Weight (BW) change was calculated as: (current BW in kilograms - ideal BW in kilograms)/ideal $\mathrm{BW} \times 100$. For patients who were unable to stand, height was estimated by using knee height equation as "height $=85.10+1.73 \times$ knee height-0.11 $x$ age" for males, "height $=91.45+1.53 \times$ knee height $-0.16 x$ age" for females [46], and by ulna length for males, height $(\mathrm{cm})=4.605 \mathrm{U}+1.308 \mathrm{~A}+28.003$, and for females, height $(\mathrm{cm})=4.459 \mathrm{U}+1.315 \mathrm{~A}+31.485$ [47], and by demispan for Males: height $(\mathrm{cm})=(1.40 \times$ demi-span in $\mathrm{cm})+57.8$ and for Females: height $(\mathrm{cm})=(1.35 \times$ demi-span in $\mathrm{cm})+60.0$ [48]. The mean height of the three measurements was considered incalculations. Body Mass Index (BMI) was calculated as wt. $(\mathrm{kg}) / \mathrm{ht} .\left(\mathrm{m}^{2}\right)$, and the cutoff points of the World health organization were used [69]. Glasgow Coma Scale is a neurological scale which aims to give a reliable and objective way of recording the conscious state of a person for initial as well as subsequent assessment. GCS is, a valid, reliable, and highly objective instrument used all over the world in multi clinical settings, conditions, especially in the emergencies' situations. GCS is considered the gold standard instrument for health care providers, including nurses to assess the level of consciousness [81].

Traumatic brain injury was classified into three categories based on Glasgow Coma Scale (GCS): mild if GCS scores $\geq 13$, moderate If GCS between (9-12), and severe head injury if GCS score $\leq 8$ [82]. 
Citation: Daradkeh G, Essa MM, AL-Maashani A, Al-Adawi S, Koshi R, et al. (2018) Omega-3 Fatty Acids Insufficiency in Post Traumatic Brain Injury Patient (TBI) Attending Neurosurgery Clinics at Khola Hospital in Muscat- Sultanate of Oman. Int J Clin Nutr Diet 4: 136 doi: https://doi.org/10.15344/2456-8171/2018/136

Page 3 of 6

\section{Food Intake}

Omega -3 FAs intake was assessed from daily food intake only (no supplementation) by using the 24 - hour recall method [70]. Through face-to-face interview with each subject. Household utensils with the different portion size of common foods were used to assist the patients to report the accurate amount of food consumed. Omega -3 adequacies were assessed by comparing the actual intake with the recommended daily allowance (RDA) [71]. After analysis of daily food intake using electronic program (super - tracker) [72]. No Estimated Average Requirements (EARs) have been established. An Adequate Intake (AI) for alpha-linolenic acid, based on the average daily intake by apparently healthy people that are therefore assumed to be adequate, has been set at $1.6 \mathrm{~g} /$ day for adult men and $1.1 \mathrm{~g} /$ day for adult women [73]. Any intake of EPA and DHA, which normally accounts for about 10 percent of total n-3 FAs in the diet, is considered to contribute to the AI for ALA. The most effective way to increase body stores of EPA and DHA is through the increased dietary intake of oil from cold-water fishspecies and from krill.

\section{Statistical Analysis}

Graph Pad Prism (version 6.0) was used for statistical analysis. Means and standard deviations (using t-tests for two means, one way Anova was used to compare between groups), two sided statistical significance was set at $\alpha \leq 0.05$ and proportions were compared by using chi-square test.

\section{Result}

71 patients in the age group 18-65, with a mean age of 27.3 years that fulfilled the eligibility criteria were enrolled in the study. The majority of patients were males (85.9\%) and (14.1\%) were females, with 6.1:1 male to female ratio. Most of the patients $(75 \%)$ were aged between $18-30.46 .5 \%$ of subjects were classified as mild TBI while $12.7 \%$ and $40.8 \%$ were classified as moderate and severe TBI respectively using the Glasgow Coma Scale. Motor vehicle accidents were the most common cause of TBI (91.7\%), followed by falls from height (8.3\%), (28.1\%) of patients were underweight $\mathrm{BMI}<18.5 \mathrm{~kg} / \mathrm{m}^{2}$ while $(16.9 \%)$ and $(7.1 \%)$ were overweight and obese respectively table 1 .

\begin{tabular}{|l|c|c|}
\hline \multicolumn{1}{|c|}{ Characteristics } & $\mathrm{n}$ & $\%$ \\
\hline Gender & & \\
\hline Male & 61 & 85.9 \\
\hline Female & 10 & 14.1 \\
\hline Body Mass Index $\left(\mathrm{kg} / \mathrm{m}^{2}\right)$ & & \\
\hline Underweight BMI $<18.5$ & 20 & 28.1 \\
\hline Normal weight, BMI $18.5-24.9$ & 34 & 47.9 \\
\hline Overweight BMI $25-29.9$ & 12 & 16.9 \\
\hline Obese $\quad$ BMI $\geq 30$ & 5 & 7.1 \\
\hline The severity of Trauma $($ Glasgow Coma Scale) & & \\
\hline Mild $\quad$ (GCS 9 - 12) & 33 & 46.5 \\
\hline Moderate $\leq 8)$ & 9 & 12.7 \\
\hline Severe & 29 & 40.8 \\
\hline TBI cause $\quad$ & 65 & 91.5 \\
\hline Vehicle accident & 6 & 8.5 \\
\hline Fall from height & & \\
\hline
\end{tabular}

Table 1: Demographic and Anthropometric Characteristics of TBI Patients.
The Average intake of omega-3FAs in both males (1.1 \pm 0.3654 $\mathrm{gm} / \mathrm{d})$ and females $(0.65 \pm 0.826 \mathrm{gm} / \mathrm{d})$ was significantly inadequate compared with the RDA (1.6 gm/d and $1.1 \mathrm{gm} / \mathrm{d})$ among males and females respectively $\mathrm{P}<0.05$ figure 1 . Omega -3 FAs deficiency rates were higher among females (40.9\%) than in males $(31.2 \%)$ TBI patients. This deficiency was positively correlated with body mass index (BMI) in both genders figure 2. The severity of Traumatic brain injury as measured by GCS has a negative effect on the intake of omega -3FAs, the intake was decreased from $(1.35 \mathrm{gm} / \mathrm{d})$ among mild TBI to $(0.85 \mathrm{gm} / \mathrm{d})$ among severe TBI male patients, While the intake was reduced from $(0.95 \mathrm{gm} / \mathrm{d})$ among mild to $(0.69 \mathrm{gm} / \mathrm{d})$ among severe TBI female patients figure 3.

\section{Discussion}

Omega-3 FAs are polyunsaturated fats found in both plants and fish play varied role in the CNS, providing a substrate for neuronal membrane phospholipids, modulating neuropterans- mission, and protecting cells from oxidative stress and inflammation through metabolites [74]. These acids have been subject of interest in the field of TBI for several years, particularly with regard to their use as a prophylactic treatment. Multiple recent reviews have emphasized the potential for these in TBI $[75,76]$. DHA deficiency is associated with aging and neurodegenerative conditions such as Alzheimer's disease, [59] while DHA consumption has been shown to improve performance on visuospatial learning and memory tasks in patients with age-related cognitive decline [77]. DHA also has antioxidant activity and mitigates the peroxidative damage of lipids and proteins in the brain [23]. Given that the same inflammatory, apoptotic, and oxidative stress mechanisms are implicated in traumatic injury to the brain, it can be reasonably hypothesized that accumulation of omega-3 FAs in the brain might also be neuroprotective in TBI.

The overall intake of omega-3 FAs in the diet of our study $(0.85 \mathrm{~g} /$ day) is lower than in most of the Western countries. For example, the average intake of omega-3 FAs was $1.2 \mathrm{~g} /$ day in the United States [78].

Inadequacy intake of omega -3 FAs may be due to several reasons such as low food intake because of loss of appetite, a decrease in sensation, and loss of motor control post-TBI. In addition to these cases, it may be due to lack of omega-3FAs content in their diet as a result of knowledge deficit about the importance of such nutrients for TBI patient among the caregiver individuals and family members. Our study finds that there is a positive association between the severity of TBI, body mass index and omega -3FAs intakes, this association may be related to the worse complications post TBI including psychological, behavioral, biochemical, metabolic and food intake. These findings are supported of other studies findings of the role of omega-3 FAs to enhancing the neuronal repair process after TBI [79].

Recent evidence, however, strongly indicates that nutritional intervention may provide a unique opportunity to enhance the neuronal repair process after TBI. To date, two omega-3 FAs, docosahexaenoic acid (DHA) and eicosapentaenoic acid (EPA) have the most promising laboratory evidence for their neuro-restorative capacities in TBI. Although both animal models and human studies of brain injuries suggest they may provide benefits. [79]. The America Society for Parenteral and Enteral Nutrition and the Society of Critical Care Medicine, state that immune-enhancing enteral formulations with n-3FAs should be used in critically ill surgical patients (including trauma) [80]. 
Citation: Daradkeh G, Essa MM, AL-Maashani A, Al-Adawi S, Koshi R, et al. (2018) Omega-3 Fatty Acids Insufficiency in Post Traumatic Brain Injury Patient (TBI) Attending Neurosurgery Clinics at Khola Hospital in Muscat- Sultanate of Oman. Int J Clin Nutr Diet 4: 136 doi: https://oi.org/10.15344/2456-8171/2018/136

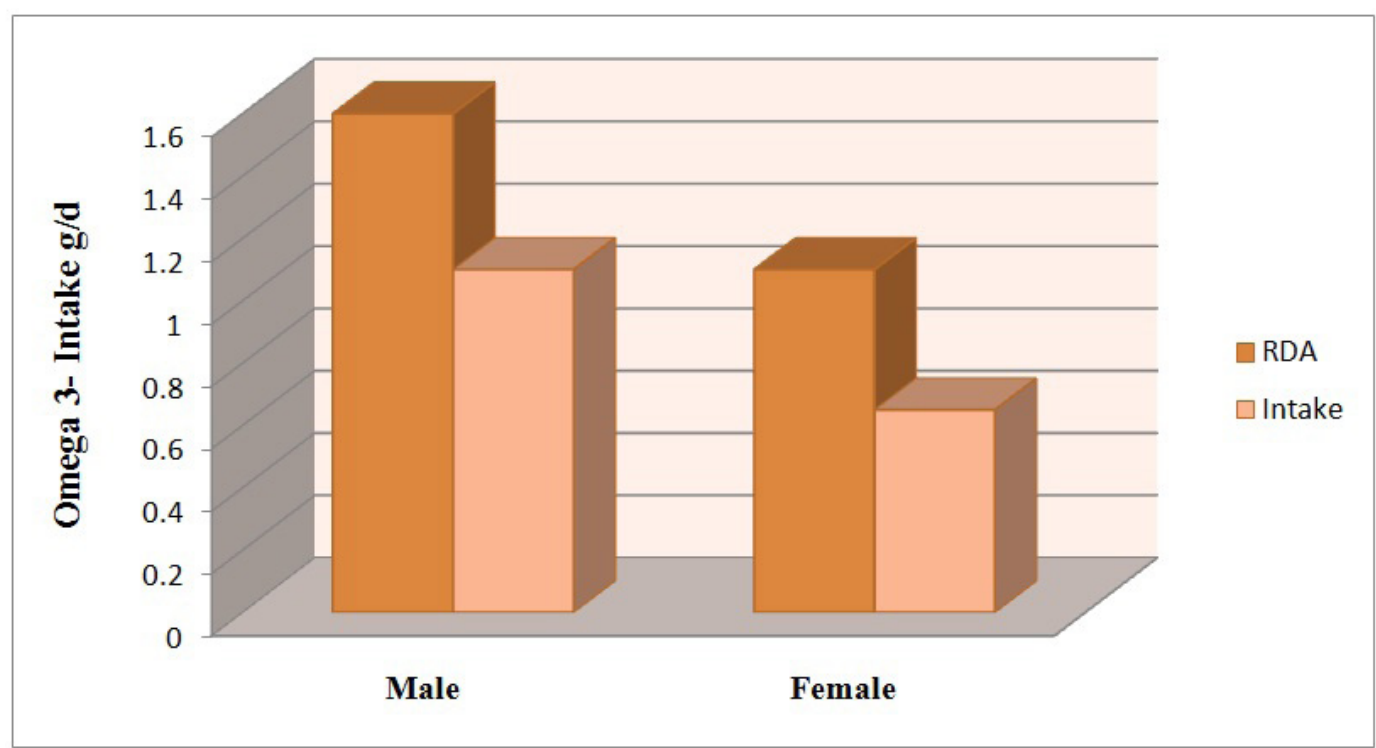

Figure 1:The Inadequacy of Omega -3FAsIntakes among TBI Patients by Gender.

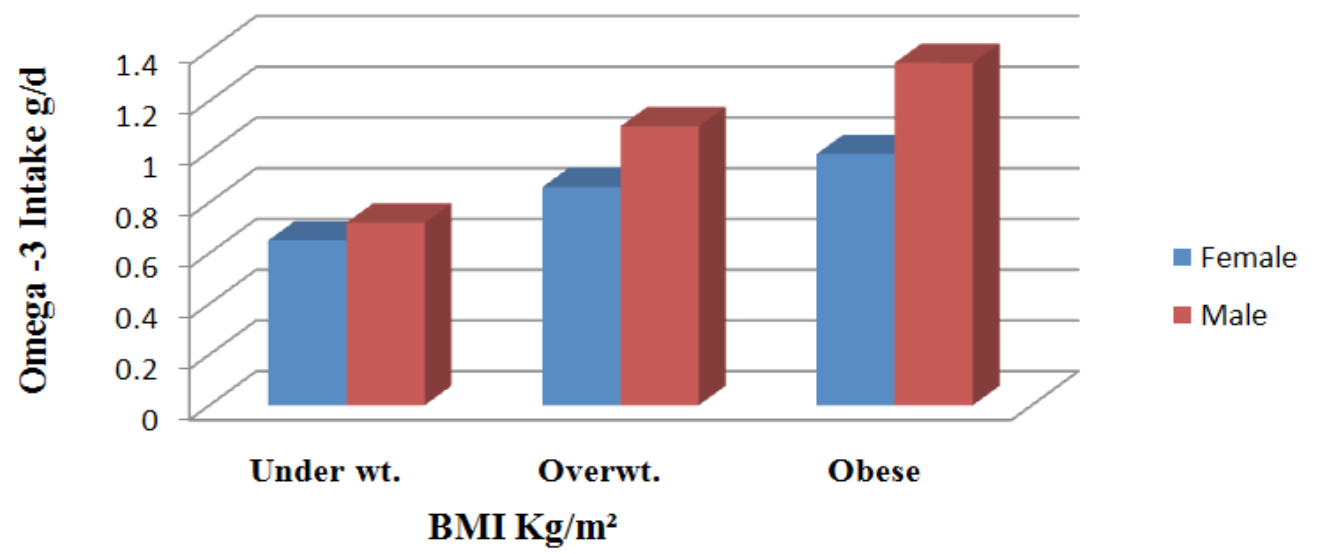

Figure 2: Omega - 3FAs Intakes with of TBI Patient with BMI and by Gender.

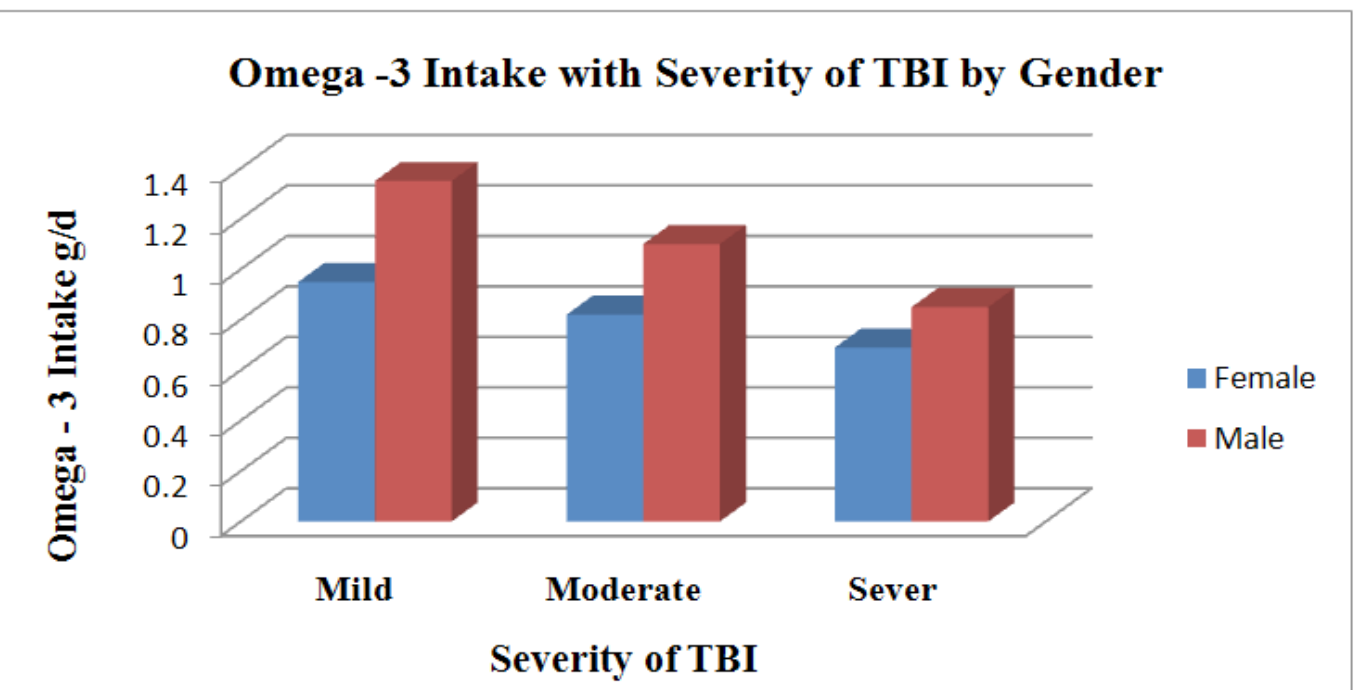

Figure 3: Omega - 3FAs Intakes with Severity of TBI Patients by Gender. 
Citation: Daradkeh G, Essa MM, AL-Maashani A, Al-Adawi S, Koshi R, et al. (2018) Omega-3 Fatty Acids Insufficiency in Post Traumatic Brain Injury Patient (TBI) Attending Neurosurgery Clinics at Khola Hospital in Muscat- Sultanate of Oman. Int J Clin Nutr Diet 4: 136 doi: https://doi.org/10.15344/2456-8171/2018/136

Page 5 of 6

\section{Conclusion}

Traumatic brain injury patients are at the severe deficiency of omega -3FAs intake through their daily dietary intake. The role of omega -3FAs in the neuronal growth and maintenance is well documented. Its intake could lessen the secondary effects of the trauma in the brain. The beneficial effects of n-3 FAs insist the clinical dietitians and neurologists work for the hand by hand to prescribe, supply, monitor and assess the dietary intake of such nutrients as well as the importance of considering their supplementation as a therapeutic option for TBI survivors. Further studies are warranted to determine the adequacy of omega- 3FAs and the effective dose for positive effects against TBI.

\section{Competing Interests}

The authors declare that they have no competing interests.

\section{References}

1. Warden D (2006) Military TBI during the Iraq and Afghanistan wars. J Head Trauma Rehabil 21: 398-402.

2. Langlois JA, Rutland-Brown W, Wald MM (2006) The epidemiology and impact of traumatic brain injury: a brief overview. J Head Trauma Rehabil 21: $375-378$.

3. Centers for Disease Control and Prevention (2007) Nonfatal Traumatic Brain Injuries from Sports and Recreation Activities - United States 2001-2005. MMWR Morb Mortal Wkly Rep 56: 733-737.

4. Omalu BI, DeKosky ST, Hamilton RL, Minster RL, Kamboh MI, et al. (2006) Chronic traumatic encephalopathy in a national football league player: part II. Neurosurgery 59: 1086-1092.

5. Guskiewicz KM, Marshall SW, Bailes J, McCrea M, Harding HP, et al. (2007) Recurrent concussion and risk of depression in retired professional football players. Med Sci Sports Exerc 39: 903-909.

6. Omalu BI, Bailes J, Hammers JL, Fitzsimmons RP (2010) Chronic traumatic encephalopathy, suicides, and parasuicides in professional American athletes: the role of the forensic pathologist. Am J Forensic Med Patho 31: $130-132$.

7. Essa MM, Vijayan RK, Castellano-Gonzalez G, Memon MA, Braidy N, et al. (2012) Neuroprotective effect of natural products against Alzheimer's disease. Neurochem Res 37: 1829-1842.

8. du Bois TM, Deng C, Bell W, Huang XF (2006) Fatty acids differentially affect serotonin receptor and transporter binding in the rat brain. Neuroscience 139: 1397-1403.

9. Wu A, Ying Z, Gomez-Pinilla F (2008) Docosahexaenoic acid dietary supplementation enhances the effects of exercise on synaptic plasticity and cognition. Neuroscience 155: 751-759.

10. Lang-Lazdunski L, Blondeau N, Jarretou G, Lazdunski M, Heurteaux C, et al. (2003) Linolenic acid prevents neuronal cell death and paraplegia after transient spinal cord ischemia in rats. J Vasc Surg; 38: 564-575.

11. Wu A, Ying Z, Gomez-Pinilla F (2004) Dietary omega-3 fatty acids normalize BDNF levels, reduce oxidative damage, and counteract learning disability after traumatic brain injury in rats. J Neurotrauma 21: 1457-1467.

12. Wu A, Ying Z, Gomez-Pinilla F (2011) The salutary effects of DHA dietary Supplementation on cognition, neuroplasticity, and membrane homeostasis after brain Trauma. J Neurotrauma 28: 2113-2122.

13. Mills JD, Bailes JE, Sedney CL, Hutchins H, Sears B, et al. (2011) Omega-3 fatty acid Supplementation and reduction of traumatic axonal injury in a rodent head injury model. J Neurosurg 114: 77-84.

14. Mills JD, Hadley K, Bailes JE (2011) Dietary supplementation with the omega-3 fatty acid docosahexaenoic acid in traumatic brain injury. Neurosurgery 68: 474-481.

15. Prins M (2008) Diet, ketones, and neurotrauma. Epilepsia 49: 111-113.

16. Shin SS, Dixon CE (2011) Oral fish oil restores striatal dopamine release after traumatic brain injury. Neurosci Lett 496: 168-171.
17. Petraglia AL, Winkler EA, Bailes JE (2011) Stuck at the bench: Potential natural Neuroprotective compounds for a concussion. Surg NeurolInt 2 : 146.

18. National Research Council (2011) Nutrition and Traumatic Brain Injury: Improving Acute and Subacute Outcomes in Military Personnel. National Academies Press.

19. Kris-Etherton PM, Taylor DS, Yu-Poth S, Huth P, Moriarty K, et al. (2000) Polyunsaturated fatty acids in the food chain in the United States. Am J ClinNutr 71: 179S-188S.

20. Raper NR, Cronin FJ, Exler J (1992) Omega-3 fatty acid content of the US food supply. J Am CollNutr 11: 304-308.

21. Tur JA, Bibiloni MM, Sureda A, Pons A (2012) Dietary sources of omega 3 fatty acids: public health risks and benefits. Br J Nutr 107: 23-52.

22. Innis SM (2003) Perinatal biochemistry and physiology of long-chain polyunsaturated fatty acids. J Pediatr 143: 1-8.

23. Innis SM (2007) Dietary ( $\mathrm{n}-3)$ fatty acids and brain development. J Nutr 137 855-859.

24. Goyens PL, Spilker ME, Zock PL, Katan MB, Mensink RP, et al. (2006) Conversion of alpha-linolenic acid in humans is influenced by the absolute amounts of alpha-linolenic acid and linoleic acid in the diet and not by their ratio. Am J Clin Nutr 84: 44-53.

25. Crawford MA (1993) The role of essential fatty acids in neural development: implications for perinatal nutrition. Am J Clin Nutr 57: 703S-709S.

26. Singh M (2005) Essential fatty acids, DHA and the human brain. Indian J Pediatr 72: 239-242.

27. Valentine RC, Valentine DL (2004) Omega-3 fatty acids in cellular membranes: a unified concept. Prog Lipid Res 43: 383-402.

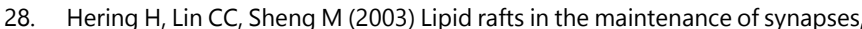
dendritic spines, and surface AMPA receptor stability. J Neurosci 23: 32623271.

29. Innis SM (2008) Dietary omega 3 fatty acids and the developing brain. Brain Res 1237: 35- 43.

30. Tsui-Pierchala BA, Encinas M, Milbrandt J, Johnson EM Jr (2002) Lipid rafts in neuronal signaling and function. Trends Neurosci 25: 412-417.

31. Stillwell W, Wassall SR (2003) Docosahexaenoic acid: membrane properties of a unique fatty acid. Chem Phys Lipids 126: 1-27.

32. Armstrong VT, Brzustowicz MR, Wassall SR, Jenski $U$, Stillwell $W$, et al. (2003) Rapid flip-flop in polyunsaturated (docosahexaenoic) phospholipid membranes. Arch Biochem Biophys 414: 74-82.

33. Chapkin RS, Wang N, Fan YY, Lupton JR, Prior IA, et al. (2008) Docosahexaenoic acid alters the size and distribution of cell surface microdomains. Biochim Biophys Acta 1778: 466-471.

34. Ehringer W, Belcher D, Wassall SR, Stillwell W (1990) A comparison of the effects of linolenic (18:3 omega 3) and docosahexaenoic (22:6 omega 3) acids on Phospholipid bilayers. Chem Phys Lipids 54: 79-88.

35. Huster D, Arnold K, Gawrisch K (1998) Influence of docosahexaenoic acid and cholesterol on lateral lipid organization in phospholipid mixtures. Biochemistry 37: 17299-17308.

36. Kafrawy O, Zerouga M, Stillwell W, Jenski LJ (1998) Docosahexaenoic acid inPhosphatidylcholine mediates cytotoxicity more effectively than other omega-3 and omega- 6 fatty acids. Cancer Lett 132: 23-29.

37. Salem N, Niebylski CD (1995) The nervous system has an absolute molecular species requirement for proper function. Mol Membr Biol 12: 131-134.

38. Smaby JM, Momsen MM, Brockman HL, Brown RE (1997) Phosphatidylcholine acyl unsaturation modulates the decrease in interfacial elasticity induced by cholesterol. Biophys J 73: 1492-1505.

39. Wassall SR, Stillwell W (2008) Docosahexaenoic acid domains: the ultimate non-raftMembrane domain. Chem Phys Lipids 153: 57-63.

40. Bazan NG (2005) Neuroprotectin D1 (NPD1): a DHA-derived mediator that protects brain and retina against cell injury-induced oxidative stress. Brain Pathol 15: 159-166.

41. Bazan NG, Musto AE, Knott EJ (2011) Endogenous signaling by omega-3 docosahexaenoic acid-derived mediators sustains homeostatic synaptic and circuitry integrity. Mol Neurobiol 44: 216-222.

42. Niemoller TD, Stark DT, Bazan NG (2009) Omega-3 fatty acid docosahexaenoic acid is the precursor of neuroprotectin D1 in the nervous system. World Rev Nutr Diet 99: 46-54. 
Citation: Daradkeh G, Essa MM, AL-Maashani A, Al-Adawi S, Koshi R, et al. (2018) Omega-3 Fatty Acids Insufficiency in Post Traumatic Brain Injury Patient (TBI) Attending Neurosurgery Clinics at Khola Hospital in Muscat- Sultanate of Oman. Int J Clin Nutr Diet 4: 136 doi: https://doi.org/10.15344/2456-8171/2018/136

Page 6 of 6

43. Weylandt KH, Chiu CY, Gomolka B, Waechter SF, Wiedenmann B, et al. (2012) Omega-3 fatty acids and their lipid mediators: towards an understanding of resolvin and protection formation. Prostaglandins Other Lipid Mediat 97: 73-82.

44. Tassoni D, Kaur G, Weisinger RS, Sinclair AJ (2008) The role of eicosanoids in the brain. Asia Pac J ClinNutr 1: 220-228.

45. Im DS (2012) Omega-3 fatty acids in anti-inflammation (pro-resolution) and GPCRs. Prog Lipid Res 51: 232-237.

46. Ahmad A, Moriguchi T, Salem N (2002) Decrease in neuron size in the docosahexaenoic acid-deficient brain. Pediatr Neurol 26: 210-218.

47. Aid S, Vancassel S, Poumes-Ballihaut C, Chalon S, Guesnet P, et al. (2003) Effect of a diet-induced n-3 PUFA depletion on cholinergic parameters in the rat hippocampus. J Lipid Res 44: 1545-1551.

48. Chalon S (2006) Omega-3 fatty acids and monoamine neurotransmission Prostaglandins Leukot Essent Fatty Acids 75: 259-269.

49. Innis SM, Gilley J, Werker J (2001) Are human milk long-chain polyunsaturated fatty acids related to visual and neural development in breast-fed term infants? J Pediatr 139: 532-538.

50. Wainwright RE, Bulman-fleming MB, Lévesque $S$, Mutsaers L, McCutcheon D, et al. (1998) A Saturated-Fat Diet during Development Alters Dendritic Growth in Mouse Brain. NutrNeurosci 1: 49-58.

51. He C, Qu X, Cui L, Wang J, Kang JX (2009) Improved spatial learning performance of fat-1 mice is associated with enhanced neurogenesis and neuritogenesis by docosahexaenoic acid. Proc Natl AcadSci USA 106: 11370-11375.

52. Farkas E, de Wilde MC, Kiliaan AJ, Luiten PG (2002) Systemic effects of dietary n-3 PUFA supplementation accompany changes of CNS parameters in cerebral hypoperfusion. Ann N Y Acad Sci 977: 77-86.

53. Catalan J, Moriguchi T, Slotnick B, Murthy M, Greiner RS, et al. (2002) Cognitive deficits in docosahexaenoic acid-deficient rats. Behav Neurosci 116: 1022-1031.

54. Bourre JM, Francois M, Youyou A, Dumont O, Piciotti M, et al. (1989) The effects of dietary alpha-linolenic acid on the composition of nerve membranes, enzymatic activity theamplitude of electrophysiological parameters, resistance to poisons and performance of learning tasks in rats. J Nutr 119: 1880-1892.

55. Carrie I, Clement M, de Javel D, Frances H, Bourre JM, et al. (2000) Phospholipid supplementation reverses behavioral and biochemical alterations induced by an $\mathrm{n}-3$ polyunsaturated fatty acid deficiency in mice. J Lipid Res 41: 473-480.

56. Yamamoto $N$, Hashimoto A, Takemoto $Y$, Okuyama $H$, Nomura $M$, et al. (1988) Effect of the dietary alpha-linolenic/linoleate balance on lipid compositions and learning the ability of rats. J Lipid Res 29: 1013-1021.

57. Pan HC, Kao TK, Ou YC, Yang DY, Yen YJ, et al. (2009) Protective effect of docosahexaenoic acid against brain injury in ischemic rats. J Nutr Biochem 20: 715-725

58. Suchy J, Chan A, Shea TB (2009) Dietary supplementation with a combination of alphalipoic acid, acetyl-L-carnitine, glycerophosphocholine, docosahexaenoic acid, andPhosphatidylserine reduces oxidative damage to the murine brain and improves cognitive Performance. Nutr Res 29: 70-74.

59. Bazan NG, Molina MF, Gordon WC (2011) Docosahexaenoic acid signalolipidomics in nutrition: significance in aging, neuroinflammation macular degeneration, Alzheimer's, and other neurodegenerative diseases. Annu Rev Nutr 31: 321-351.

60. Yurko-Mauro K, McCarthy D, Rom D, Nelson EB, Ryan AS, et al. (2010) Beneficial effects of docosahexaenoic acid on cognition in age-related cognitive decline. Alzheimers Dement 6: 456-464.

61. Bistrian BR, Askew W, Erdman JW Jr, Oria MP (2011) Nutrition and traumatic brain injury: a perspective from the Institute of Medicine report. JPEN Parenter EnteralNutr 35: 556-559.

62. Garbagnati F, Cairella G, De Martino A, Multari M, Scognamiglio U, et al (2009) Is antioxidant and $n-3$ supplementation able to improve functional status inpost stroke patients? Results from the Nutristroke Trial. Cerebrovasc Dis 27: $375-383$

63. Poppitt SD, Howe CA, Lithander FE, Silvers KM, Lin RB, et al. (2009) Effects of moderate-dose omega-3 fish oil on cardiovascular risk factors and mood after ischemic stroke: a randomized, controlled trial. Stroke 40: 3485-3492.
64. Yoneda $H$, Shirao $S$, Kurokawa $T$, Fujisawa $H$, Kato $S$, et al. (2008) Doeseicosapentaenoic acid (EPA) inhibit cerebral vasospasm in patients after aneurysmalsubarachnoid hemorrhage? Acta Neurol Scand 118: 54-59.

65. Cao DH, Xu JF, Xue RH, Zheng WF, Liu ZL, et al. (2004) Protective effect of chronic ethyl docosahexaenoate administration on brain injury in ischemic gerbils. Pharmacol Biochem Behav 79: 651-659.

66. Green P, Glozman S, Weiner L, Yavin E, et al. (2001) Enhanced free radical scavenging and decreased lipid peroxidation in the rat fetal brain after treatment with ethyl docosahexaenoate. Biochim Biophys Acta 1532: 203212.

67. Okada M, Amamoto T, Tomonaga M, Kawachi A, Yazawa K, et al. (1996) The chronic administration of docosahexaenoic acid reduces the spatial cognitive deficitfollowing transient forebrain ischemia in rats. Neuroscience 71: $17-25$.

68. Stratton RJ, King C, Elia M (2004) Simple cost-analysis of changes in hospitallength of stay with oral nutritional supplements from randomized controlledtrials. Clin Nutr 23: 906-915.

69. Bassey EJ (1986) Demi-span as a measure of skeletal size. Ann Hum Biol 13: $499-502$.

70. Lim SL, Ong KC, Chan YH, LoceWC, Ferguson $\mathrm{M}$, et al. Malnutrition and its impact on the cost of hospitalization, length of stay, readmission and 3years mortality. Clin Nutr 31: 345-350.

71. Report of the Panel on Macronutrients, Subcommittees on Upper Reference Levels of Nutrients and Interpretation and Uses of Dietary Reference Intakes, and the Standing Committee on the Scientific Evaluation of Dietary Reference Intakes. Dietary reference intakes for energy, carbohydrate, fiber, fat, fatty acids, cholesterol, protein, andamino acids (macronutrients) (2005) Washington, DC: National Academies Press.

72. Ahuja JKA, Montville JB, Omolewa-Tomobi G, Heendeniya KY, Martin CL, et al. (2012) USDA Food and Nutrient Database for Dietary Studies, 5.0. USDA, Agricultural Research Service, Food Surveys Research Group, Beltsville, MD.

73. IOM (2005) Dietary Reference Intakes for energy, carbohydrate, fiber fat, fatty acids, cholesterol, protein, and amino acids (macronutrients) Washington, DC: The National Academies Press.

74. Niemoller TD, Stark DT, Bazan NG (2009) Omega-3 fatty acid docosahexaenoic acid Is the precursor of neuroprotectin D1 in the nervous system. World Rev Nutr Diet 99: 46-54

75. Hasadsri L, Wang BH, Lee JV, Erdman JW, Llano DA, et al. (2013) Omega-3 fatty acids as a putative treatment for traumatic brain injury. $J$ Neurotrauma 30: 897-906

76. Michael-Titus AT, Priestley JV (2014) Omega-3 fatty acids and traumatic neurological injury: from neuroprotection to neu- roplasticity? Trends Neurosci 37: 30-38.

77. Yurko-Mauro K, McCarthy D, Rom D, Nelson EB, Ryan AS, et al. (2010) Beneficial effects of docosahexaenoic acid on cognition in age-related cognitive decline. Alzheimers Dement 6: 456-464.

78. Suzuki S, Platz EA, Kawachi I, Willett WC, Giovannucci E, et al. (2002) Intakes of energy and macronutrients and the risk of benign prostatic hyperplasia. Am J Clin Nutr 75: 689-697.

79. Hasadsri L, Wang BH, Lee JV, Erdman JW, Llano DA, et al. (2013) Omega-3 Fatty Acids as a Putative Treatment for Traumatic Brain Injury. Journal of Neurotrauma 30: 897-906.

80. McClave SA, Taylor BE, Martindale RG, Warren MM, Johnson DR, et al. (2009) Guidelines for the provision and assessment of nutrition support therapy in the adult critically ill patient: Society of Critical Care Medicine (SCCM) and American Society for Parenteral and Enteral Nutrition (A.S.P.E.N.). JPEN J Parenter Enteral Nutr 33: 277-316.

81. Siobhan M (2014) The Glasgow Coma Scale 40 years on a review of its practical use. British Journal of Neuroscience Nursing.

82. Juliet F, Claranne M (2001) The History of the Glasgow Coma Scale: Implications for Practice. Critical Care Nurse 23: 52-58. 